\title{
GEOTECHNICAL FOUNDATION CONDITIONS OF MESOLOGION SWIMMING POOL CENTER
}

\author{
Douveas N. ${ }^{1}$, Kavadia D. ${ }^{1}$, and Papadopoulou P. ${ }^{1}$ \\ ${ }^{1}$ HYDRONET, Consulting office for geology and geotechnics, Panepistimiou Str.52-54, 26442, \\ Patras, hydronet@tee.gr
}

\begin{abstract}
Although geotechnical tests are standard and commonly used in determining the foundation type to be applied, in some cases the use of in-situ tests are essential in order to obtain the correct values needed in the geotechnical calculations. In the case of the foundation of Mesologi Swimming-pool Center, an attempt was made to propose a foundation type, suitable from geotechnical point of view, for sediments that lie very close to the sea! The selection of the most suitable foundation type encloses the examination of several parameters. The subsoil there, consists of soft, fine grained, low plasticity materials, CL to SL with alternations of high plasticity clay layers $\mathrm{CH}$. Additionally, the groundwater level is 0,8 meters under the soil surface, demonstrating constant saturation conditions. The combination of soft subsoil layers quality and the high level of groundwater leads to difficult foundation conditions in relation to immediate and secondary consolidation settlement. Geotechnical calculations and calculations of settlement were performed and the most suitable foundation type was semi-compensated mat foundation.
\end{abstract}

Key words: SPT, CPT, semi-compensated mat, soft soil.

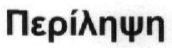

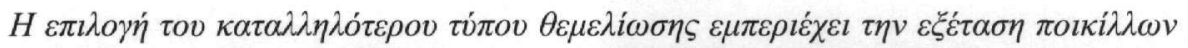

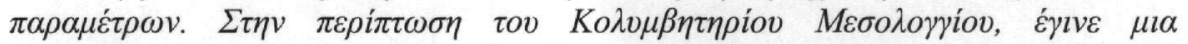

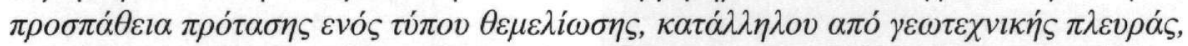

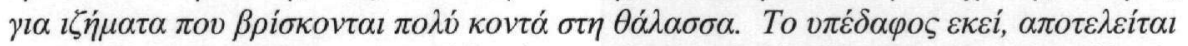

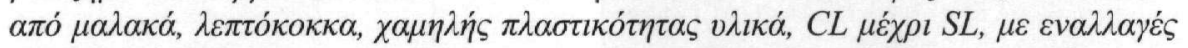

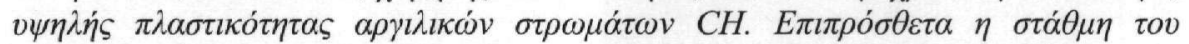

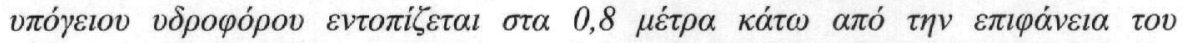

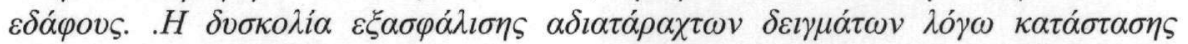

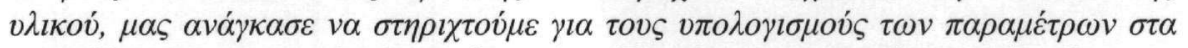

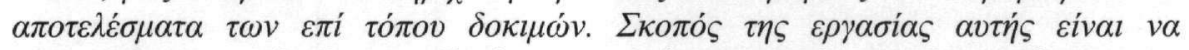

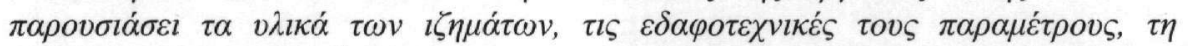

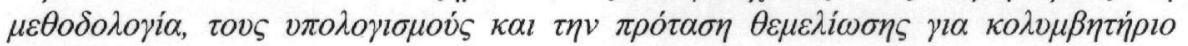

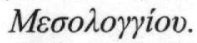

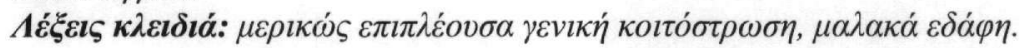




\section{Introduction}

In areas (e.g. the Mesologi Swimming-pool Center foundation area), where the ground - water level lies close to the soil surface and the subsoil is very soft, the geotechnical testing and the data accuracy are of great importance. Usually the geotechnical calculations in such cases result in a narrow range of values that are acceptable for the foundation. Detailed examination of the soil parameters and accuracy when conducting the sampling and laboratory or in situ testing are very important. The selection of the suitable foundation type depends on the correct evaluation of the results. The most proper solution should be based on the bearing capacity and the allowable settlement calculation results.

Standard Penetration tests provided several useful correlations such as:
a. consistency of clayey soils
b. undrained shear strength $\mathrm{Cu}$
c. the over consolidation ratio OCR
d. relation between $\mathrm{N}$ value, relative density, and angle of friction in sands.

Along with the classical sampling methods (e.g. SPT tests and laboratory testing) the use of electrical piezocone CPT was considered for the geotechnical evaluation. The CPT test is a well known method and can be used to determine the materials in a soil profile and estimate their engineering properties. The cone penetrometers measure $a$. the cone resistance qc to penetration developed by the cone and $\mathrm{b}$. the frictional resistance $\mathrm{fc}$. The ratio of $\mathrm{fs}$ and qc gives the value of friction ratio Rf. This is a very important piece of information for the foundation planning, especially because no boreholes are necessary to acquire them.

SPT and CPT tests were preferred in this occasion because the soil is too soft and there is an uncertainty as to whether the samples could be transferred to the laboratory (for further laboratory testing) and remain undisturbed.

\section{Geology, Palaeogeographic evolution}

During Holocene, large quantities of sediments carried from the river system of Acheloos at west and the river system of Evinos at east accumulated in the greater area of Mesologi basin. The sedimentation created two border delta fans, these of Acheloos and Evinos. The Acheloos platform extended rapidly to Ionion Sea, to the $\mathrm{SW}$, after filling the superficial region of the karst hills of Echinades (Psilovikos 1995). At east, a smaller river system created the delta of Evinos. This platform could not evolve to the south, because of the big depth and the steep bottom of the Patraikos basin, so it evolved

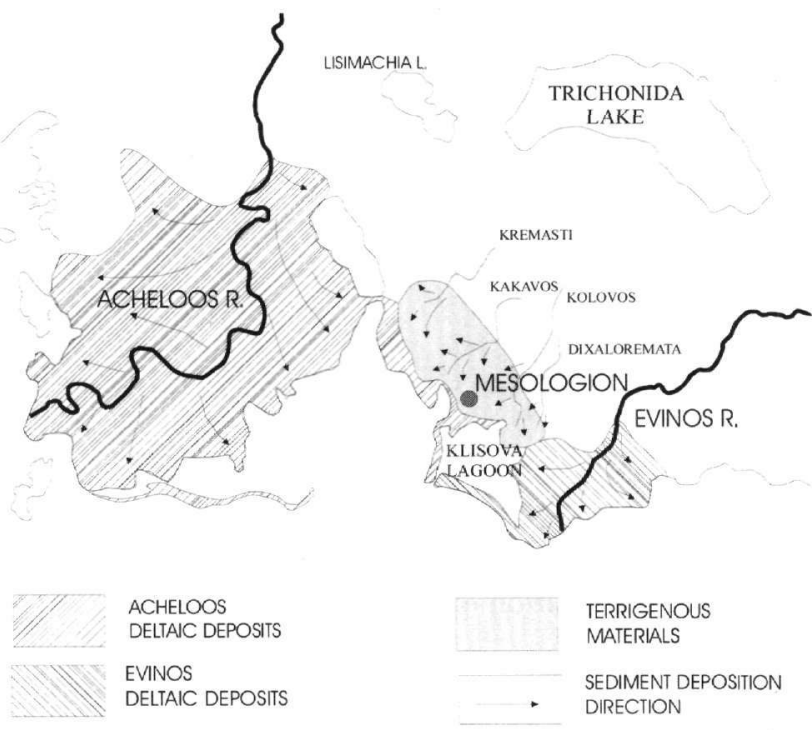
to the west (Fig. 1).

Figure 1 - Fan Deposits in Mesologi area 
The sedimentation faces of Mesologi basin ends on the top with red fine coarse terigenous material transported by the torrents Kremasti, Kakavos, Kolovos, and Dixaloremata located at the NNE side of Mesologi.

Due to the sedimentary processes which contributed to the formation of the sedimentary basin of Mesologi, the expected substrata layers are soft clays and fine coarse sands with red silt sands on the top of the stratigrafical column. This information needed to be further explored for the planning of the foundation of Mesologi Swimming-pool Center.

\section{Materials and Methods}

The geotechnical research was operated in an area of 20.000 sq. meters close to the Mesologi harbor, where the Swimming-pool Center will be constructed. The exact location of the foundation depends on the geotechnical results.

The following geotechnical methods were applied :

1. Rotation drillings with continuous sampling up to the depth of 15-25 meters. In the project area, seven exploratory core borings were drilled (Fig. 1). Five borings were drilled up to the depth of 15 meters (G1-G3 and G6-G7) and two borings were drilled up to the depth of 25 meters (G4 and G5) (Fig. 2).

2. Standard penetration tests in every meter of drilling (SPT).

3. Cone penetration tests (CPT) up to the respective depth of the drillings and

4. Laboratory tests for the soil classification and loading and shearing tests.

\subsection{Sampling drillings}

A total of 125 meters of boring by rotation with continuous sampling have been conducted. The typical stratigraphic column with the units of layers (I-VIII) are presented in Table 1.

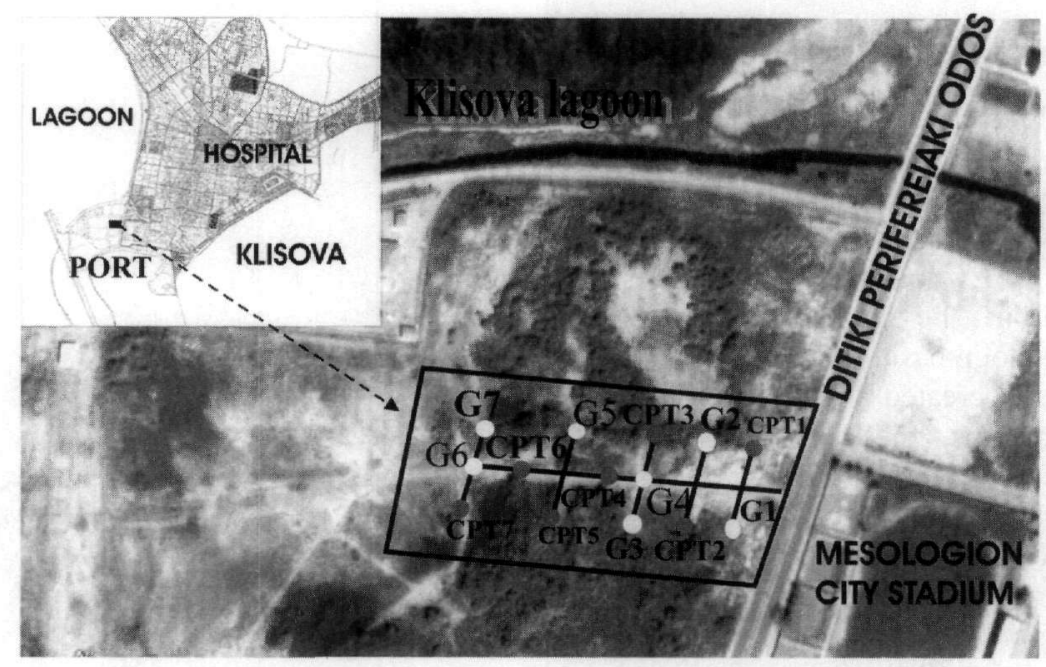

Figure 2 - Position of borings G1-7 and CPT1-7 in Mesologi Swimming -pool Center

\subsection{In situ tests}

For the determination of the load capacities of the subsoil layers in this specific building area, the methods of in situ tests SPT and CPT were applied (Fig.2).

SPT tests have been conducted in 41 parts of the drillings.

The N values of the SPT tests in the borings G1 -7 give the following information: 
The soil type up to $9 \mathrm{~m}$ depth is low plasticity clayey silt soft with poor geomechanical parameters. A mean $\mathrm{N}$ value in the depth of $3 \mathrm{~m}$ under surface, proposed as surface of embedment, with $\mathrm{N}=5$ is accepted (Table 1 ). The soil type is low plasticity clayey silt .In the next layer until the depth of $9 \mathrm{~m}$ the $\mathrm{N}$ value increases gradually. The layer from $9-11 \mathrm{~m}$ in the borings $\mathrm{G} 1-\mathrm{G} 7 \mathrm{is}$ recognized as high plasticity clay $\mathrm{CH}$ with $\mathrm{N}=4$. Deeper than $11 \mathrm{~m}$ the average value of $\mathrm{N}$ is greater than 20 blows suggesting that the geotechnical characteristics of the ground are significantly improved.

Table 1 - Soil type (borings G1-7) in depths between 1-3.7 m

\begin{tabular}{|l|l|l|l|}
\hline \multicolumn{1}{|l|}{ Boring } & \multicolumn{1}{|c|}{ Depth $(\mathbf{m})$} & \multicolumn{1}{|c|}{ Soil type } & $\begin{array}{l}\text { Number of } \\
\text { blows (SPT) }\end{array}$ \\
\hline G1 & $1-6$ & Low plasticity clayey silt & \\
\hline G2 & $2.5-2.95$ & Low plasticity clayey silt & $4 / 4 / 5$ \\
\hline G3 & $3-4.7$ & Low plasticity clayey silt & $2 / 2 / 1$ \\
\hline G4 & $1.4-4.5$ & Medium plasticity silty sand & $2 / 2 / 1$ \\
\hline G5 & $2.2-3.7$ & Low plasticity clayey silt & $2 / 2 / 3$ \\
\hline G6 & $2.3-3.7$ & Low plasticity clayey silt & $2 / 2 / 4$ \\
\hline G7 & $0.5-3.7$ & Grey sand & $2 / 2 / 3$ \\
\hline
\end{tabular}

Table 2 - Comparison of $q_{c}, f_{s}$, and $R_{f}$ values and soil layers after CPT Test with the average number of blows determined from the SPT - tests

\begin{tabular}{|l|l|l|l|l|}
\hline \multicolumn{1}{|c|}{ Depth } & $\begin{array}{l}\text { Average } \\
\text { N value }\end{array}$ & Layer & \multicolumn{1}{|c|}{ Soil type } & \multicolumn{1}{c|}{$\begin{array}{c}\text { Average parameters in } \\
\text { MPa }\end{array}$} \\
\hline $0-3$ & - & I-III & RED SAND $($ SM $)$ & $\mathrm{q}_{\mathrm{c}}=2.9, \mathrm{f}_{\mathrm{s}}=0.13, \mathrm{R}_{\mathrm{f}}=4.84 \%$ \\
\hline $3-6$ & 5 & IV & CLAYEY-SILT $(\mathrm{CL})$ & $\mathrm{q}_{\mathrm{c}}=0.62, \mathrm{f}_{\mathrm{s}}=0.04, \mathrm{R}_{\mathrm{f}}=4.79 \%$ \\
\hline $6-9,6$ & 18 & $\mathrm{~V}$ & $\begin{array}{l}\text { COARSE GRAINED } \\
\text { RED-GREY SANDY } \\
\text { SILT (SM) }\end{array}$ & $\mathrm{q}_{\mathrm{c}}=8.89, \mathrm{f}_{\mathrm{s}}=0.37, \mathrm{R}_{\mathrm{f}}=4.25 \%$ \\
\hline $9,6-11,4$ & 4 & VI & $\begin{array}{l}\text { BLACK CLAY } \\
(\text { CH) }\end{array}$ & $\mathrm{q}_{\mathrm{c}}=0.78, \mathrm{f}_{\mathrm{s}}=0.02, \mathrm{R}_{\mathrm{f}}=39 \%$ \\
\hline $11,4-14,5$ & 20 & VII & GREY SAND $($ SM $)$ & $\mathrm{q}_{\mathrm{c}}=5.48, \mathrm{f}_{\mathrm{s}}=0.14, \mathrm{R}_{\mathrm{f}}=2.72 \%$ \\
\hline $14,5-21$ & 34 & VIII & $\begin{array}{l}\text { CLAYEY SILT } \\
\text { SANDY } \\
\text { SILT(SM/SC) }\end{array}$ & $\mathrm{q}_{\mathrm{c}}=1.77, \mathrm{f}_{\mathrm{s}}=0.04, \mathrm{R}_{\mathrm{f}}=2.54 \%$ \\
\hline
\end{tabular}




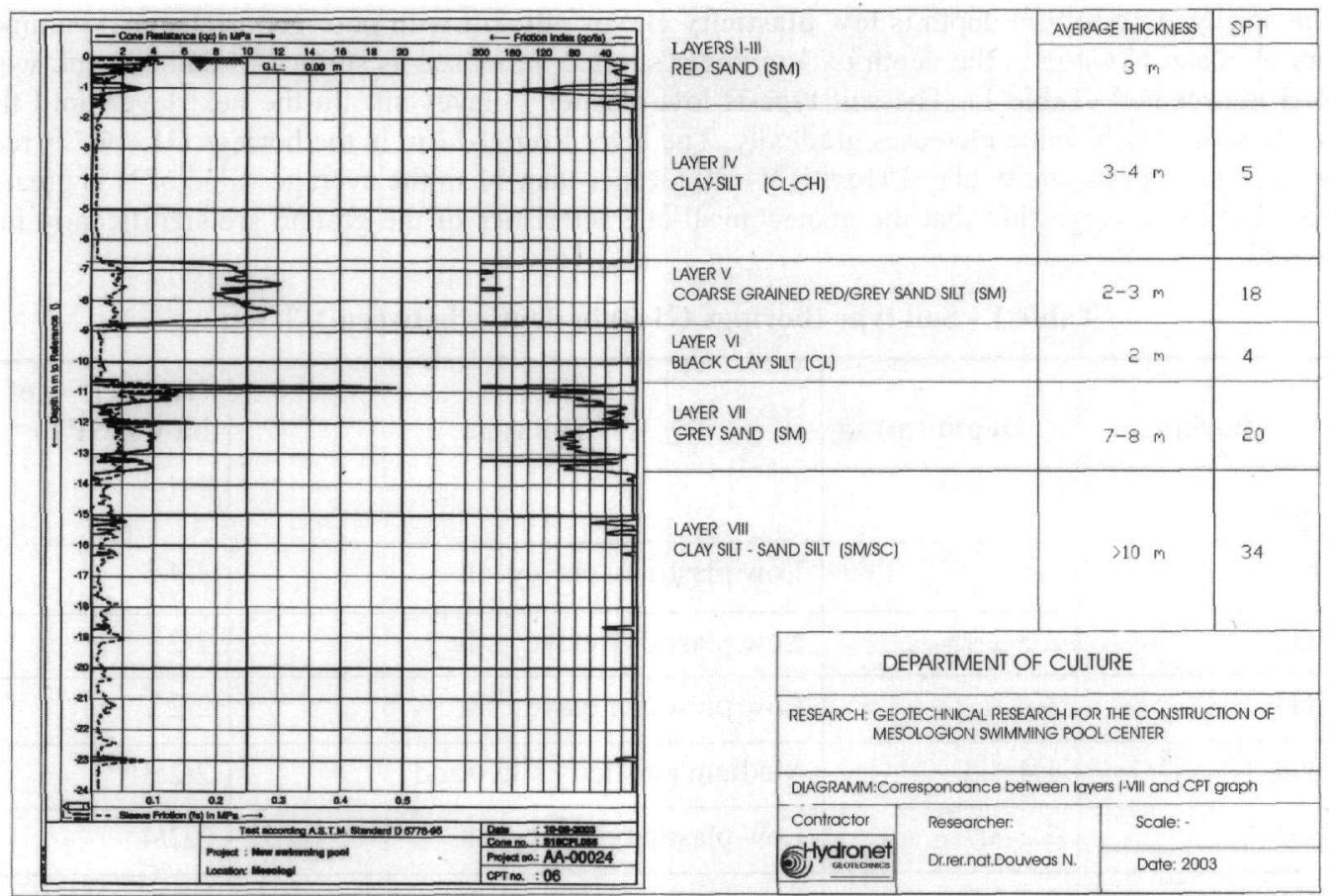

Figure 3 - Typical CPT graph showing the soil groups and compared to the SPT test results

After using the $q_{c}$ and $R_{f}$ values from Figure 3, the soil types in every layer up to 21 meters in depth were determined and are presented in Table 2. The results of both in-situ SPT and CPT tests correlate well with the type of layer found on site.

\subsection{Tests of soil classification}

114 samples were examined in the laboratory with sieves or/and aerometer (Diagram 2).

The statistical data processing of grain size analyses shows that the $56 \%$ of the samples were grained without plasticity SM-SC, the $29 \%$ were of low plasticity CL, the $7,8 \%$ were samples CL-ML and only $6 \%$ were $\mathrm{CH}$, high plasticity, clay.

\section{Diagram 2 - Grain size curves of the most representative samples}

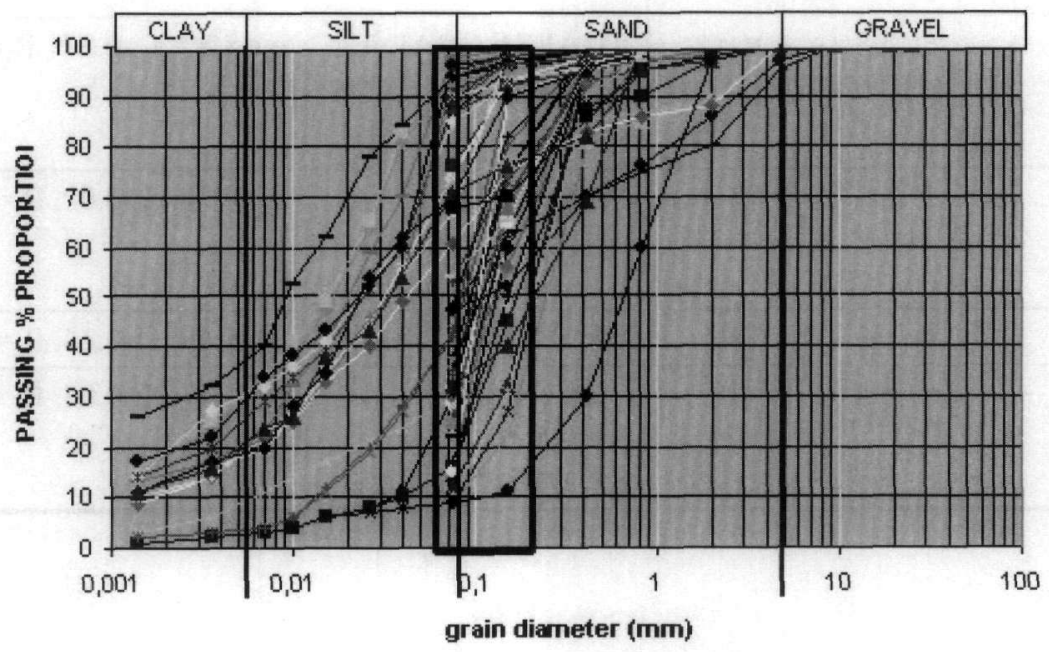




\section{Geotechnical calculations}

\subsection{Bearing capacity and allowable bearing capacity}

Symbols: $\mathrm{q}_{\mathrm{ult}}=$ ultimate bearing capacity, $\mathrm{q}_{\mathrm{net}}=$ net bearing capacity,

$\mathrm{q}_{\mathrm{u}(\mathrm{all})}=$ ultimate allowable pressure, $\mathrm{q}_{\text {net (all) }}=$ net allowable pressure,

\section{Mayerhoff Method}

For Layer IV CLAYEY-SILT (CL ) $\quad \mathrm{N}=5 \quad \mathrm{C}_{\mathrm{u}}=13,8 \mathrm{kPa} \quad \mathrm{D}_{\mathrm{f}}=3 \mathrm{~m}$

Ultimate bearing capacity: $\mathrm{q}_{\mathrm{ult}}=5,14 \mathrm{C}_{\mathrm{u}}\left(1+0,195 \frac{B}{L}\right)\left(1+0,4 \frac{D_{f}}{B}\right)$

$\left[\mathrm{B}=\right.$ mat width $=$ e.g. $70 \mathrm{~m}, \mathrm{~L}=$ mat length $=75 \mathrm{~m}, \mathrm{D}_{\mathrm{f}}=$ depth of embedment $=3 \mathrm{~m}, \mathrm{C}_{\mathrm{U}}=$ undrained clay cohesion $=0,173 \mathrm{Kgr} / \mathrm{cm}^{2}=1,73 \mathrm{ton} / \mathrm{m}^{2}$ (this is the least favorable laboratory value)].

Ultimate soil bearing capacity $=\mathrm{q}_{\mathrm{ult}}=10,92 \mathrm{ton} / \mathrm{m}^{2}$. The net allowable bearing capacity is $\mathrm{q}_{\text {net (all) }}$ $=10,92 / 3=3,64 \operatorname{ton} / \mathrm{m}^{2}$. The geostatic presure $\sigma$ is: $\sigma=5,68 \mathrm{ton} / \mathrm{m}^{2}$ and when added to the net allowable bearing capacity is: ultimate net allowable pressure $=\mathrm{q}_{\text {net (all) }}^{\prime}=9,32 \mathrm{ton} / \mathrm{m}^{2}=0,93$ $\mathrm{Kgr} / \mathrm{cm}^{2}$, higher of the active stress $\sigma_{V_{0}}=0,815 \mathrm{Kgr} / \mathrm{cm}^{2}$.

\section{Bowles Method (for large settlements)}

$\mathrm{q}_{\text {net(all) }}=11.98 \mathrm{~N}^{\prime}\left(\frac{3.28 B+1}{3.28 B}\right)^{2} \mathrm{~F}_{\mathrm{d}} \frac{S}{25}\left(\mathrm{~N}^{\prime}=\right.$ corrected blow number $\mathrm{N}$ of the $\mathrm{SPT}=5, \mathrm{~S}=$ allowable settlement $=3 "=75 \mathrm{~mm}$ ).

$\mathrm{F}_{\mathrm{d}}=$ depth factor $=1+0.33 \frac{D_{f}}{B} \leq 1.33 \quad \mathrm{D}_{\mathrm{f}}=3 \mathrm{~m} \quad \mathrm{~B}=70$

$\mathrm{mF}_{\mathrm{d}}=1+0.33 \frac{3}{70}=1.00 \leq 1.33$ O.K.

$\mathrm{q}_{\text {net(all) }}=183.08 \mathrm{KN} / \mathrm{m}^{2}$

Coefficient of correction because of hydrostatic pressure $\mathrm{C}_{\mathrm{w}}$ :

$\mathrm{C}_{\mathrm{w}}=0.5+0.5 \frac{D_{W}}{D_{f}+B},\left(\mathrm{D}_{\mathrm{w}}=\right.$ hydrostatic level depth, here $=0.8, \mathrm{D}_{\mathrm{f}}=$ foundation depth=3m, $\left.\mathrm{B}=70 \mathrm{~m}, \mathrm{C}_{\mathrm{w}}=0.5\right)$

The net allowable pressure with hydrostatic level in the depth of $0.8 \mathrm{~m}$ from the surface of embedment is: $\mathrm{q}_{\text {net(all) }}=183,0 \times 0.5=92,5 \mathrm{KN} / \mathrm{m}^{2}=0,925 \mathrm{Kgr} / \mathrm{cm}^{2}>$ of the active stress $\sigma_{V_{0}}=$ $0.815 \mathrm{Kgr} / \mathrm{cm}^{2}$.

\subsection{Settlement calculation}

We assume that the foundation mat is rigid and centrically loaded. As far as the soil is concerned we assume that the Layer IV will hold long ranged settlement. The Layer V, with the additional pressure that was estimated to be applied because of the construction, will practically remain incompressible. With the rapid loading of the foundation layer, absorption of the immediate settlements will be achieved. Additionally, the placement of a preconsolidated gravel layer under 
the foundation will be used as a filter for the expansion of the overpressures that will evolve in the clay layer IV pore water.

After loading, the active stress in the depth of 3 meters under foundation, is shaped as following:

Initial stresses: $\sigma_{\mathrm{vo}}=5,68+5,19=10,87 \mathrm{t} / \mathrm{m}^{2}$,

Active stress after the foundation: $\sigma_{\mathrm{vT}}=8,15+5,19=13,34 \mathrm{t} / \mathrm{m}^{2}$ whereas on the surface of embedment, because of the foundation and the filter preconsolidated foundation layer stress of $8,15 \mathrm{ton} / \mathrm{m}^{2}$ is applied. The additional stress that will cause settlement is: $8,15-5,68=2.46 \mathrm{ton} / \mathrm{m}^{2}$ (Table 7).

Table 7 - Parameters for the settlement calculation

\begin{tabular}{|c|c|c|c|c|c|}
\hline Layer & Soil parameters & Depth (m) & Initial stresses & $\begin{array}{l}\text { Active } \\
\text { stress } \\
\text { ton } / \mathrm{m} 2\end{array}$ & \\
\hline & & 0 & \multirow{2}{*}{$\sigma v O=5,68$} & \multirow[t]{2}{*}{$\sigma \mathrm{uT}=8,15$} & \multirow{2}{*}{$\begin{array}{l}\text { foundation } \\
\text { surface }\end{array}$} \\
\hline I-III & $\begin{array}{l}\gamma \alpha=1,8 \\
\gamma s=1,93\end{array}$ & 3 & & & \\
\hline \multirow[t]{2}{*}{ IV } & \multirow{2}{*}{$\begin{array}{l}\gamma \mathrm{s}=1,73 \\
\mathrm{Cc}=0.32 \\
\mathrm{e}=1,28 \\
\mathrm{Cv}=7 * 10-4 \\
\mathrm{~cm} 2 / \mathrm{s}\end{array}$} & 6 & $\sigma \vee \mathrm{v}=10,87$ & & Depth level $3 \mathrm{~m}$ \\
\hline & & 6 & & & \\
\hline $\mathrm{V}$ & $\gamma \mathrm{s}=1,93$ & 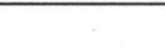 & & & \\
\hline
\end{tabular}

The total settlement after the consolidation will be: $\mathrm{S} \sigma=\mathrm{H} \mathrm{Cc} /\left(1+\mathrm{e}_{\mathrm{o}}\right) \log (13,34 / 10,87)=3 \chi$ $0,32 /(1+1,28) \log 1,22=$

$=0,420,086$, so $\mathrm{S} \sigma=0,036, \mathrm{~m}=3,6 \mathrm{~cm}$.

The value calculated is, within the value range, normally accepted. The settlement 2 years after the loading is calculated as follows: $\mathrm{Tv}=\mathrm{Cv} \cdot \mathrm{t} / \mathrm{H}^{2}=710^{-4} \mathrm{~cm}^{2} / \mathrm{s} 36586400 / 910^{4}=0,24$. According to the curves that arise from the Terzaghi differential equation, it comes up the average consolidation ratio is $U=0,35$. The calculated settlement after two years will be: $S \sigma(2)=0,036 \times 0,55=0,0198$ $\mathrm{m}=2 \mathrm{~cm}$. The time for the achievement of the $90 \%$ of the settlement $(\mathrm{U}=0,9$ and $\mathrm{Tu}=0,82)$ is calculated as following : $\mathrm{t}=\mathrm{H}^{2}$. Tu/Cv $=300^{2} \times 0,82 / 5 \times 10^{-4}=4,6$ years. This value is normally accepted.

\subsection{Proposed type of foundation}

The net average applied pressure on soil is: $\mathrm{q}=\mathrm{Q} / \mathrm{A}-\gamma \mathrm{D}_{\mathrm{f}}(\mathrm{Q}=$ loads, $\mathrm{A}=$ foundation surface, $\gamma=$ wet unit weight, $\mathrm{D}_{\mathrm{f}}=$ depth of embedment). The ultimate pressure caused by the live and dead loads on the mat of construction is calculated to be $Q / A=4.85 \mathrm{ton} / \mathrm{m}^{2}$. On the other hand, in the depth of 3 $\mathrm{m} \mathrm{D}_{\mathrm{f}}=5,68 \mathrm{ton} / \mathrm{m}^{2}$. C, the total loads on the surface of the embedment layer in the depth of $3 \mathrm{~m}$ corresponds to $4.85 \mathrm{ton} / \mathrm{m}^{2}>5.68 \mathrm{ton} / \mathrm{m}^{2}=\mathrm{D}_{\mathrm{f}}$. Consequently, the type of semi-compensated mat foundation is especially recommended (Douveas 2003). 


\section{Results and discussion}

In the case of Mesologi Swimming-pool Center a semi-compensated mat foundation is proposed. The loads due to the foundation applied to the ground were calculated to be less than the preexisting loads.

This conclusion is based on the results of the in-situ testings. Rigid core samples for geotechnical testing in the laboratory is almost impossible for materials that are soft and fluid as in this case. Thus, in-situ testing is more reliable. Data obtained from in-situ CPT and SPT testing can be used in order to determine important geotechnical parameters necessary for foundation determination. Although such tests are standard their application in this case (Mesollogi) is essential due to the nature of the materials.

\section{Acknowledgements}

The authors wish to express appreciation to Associate Prof. Dr. Mylonakis Dep. for Soil Mechanics Uni. Patras for his opinion in order this problem to be resolved.

\section{References}

Anagnostopoulos, and Papadopoulos, 2002. Surface Foundation.

Athanasopoulos, G., 2003. Foundation lessons, Patras University Publications.

Barnes, G.E., 2000. Soil Mechanics-Principles and Practise.

Braja, M., 1995. Das. Principles of Foundation Engineering.

Budhu, Muni, 2000. Soil Mechanics \& Foundations.

Douveas, N., 2003.Geotechnical investigation - study for the construction of the Mesologion swimming pool center, Mesologion.

Psilovikos, A., 1995. Estimation study of the Acheloos basins' water content for the development and environmental step-up of the lagoons delta and of the whole region. Thessaloniki. 